\title{
KIMBERLITE AT-56: A MANTLE SAMPLE FROM THE NORTH CENTRAL SUPERIOR CRATON, CANADA
}

\author{
Ken Armstrong ${ }^{1}$, Tom Nowicki' ${ }^{2}$ and George $\operatorname{Read}^{3}$ \\ ${ }^{1}$ Navigator Exploration Corp., Canada $;{ }^{2}$ Mineral Services Canada Inc., Canada $;{ }^{3}$ Canabrava Diamond Corp., Canada
}

\section{INTRODUCTION}

Kimberlite AT-56, discovered in February 2001, represents the most recent addition to the Attawapiskat kimberlite cluster, located in the James Bay Lowlands of Ontario, Canada. The nineteen kimberlites of the ca 180Ma Attawapiskat cluster intrude flat lying shallow marine rocks of the Paleozoic Moose River basin, which in turn unconformably overlie the eastern extension of the Sachigo Subprovince of the Archean Superior Craton (Kong et al., 1999; Heaman and Kjarsgaard, 2000).

\section{KIMBERLITE AT-56}

AT-56 is a small kimberlite with a surface diameter of approximately $40 \mathrm{~m}$ and a steep southeastern plunge of about seventy degrees. The body lies beneath approximately $3 \mathrm{~m}$ of overburden, consisting of mixed black organic material (peat) and glacial till. Overburden thickness may increase towards the edges of the kimberlite where it is in contact with adjacent country rocks. AT-56 is a medium to coarse grained, matrix to locally near-clast supported kimberlite with abundant olivine, garnet, ilmenite, clinopyroxene and mica macrocrysts in a green-black to orange-black matrix. Average macrocryst size varies from $<0.5 \mathrm{~mm}$ to $1.5 \mathrm{~mm}$. Mantle derived xenoliths are very rare, and where identified tend to be in the form of mineral pairs (i.e. olivine plus garnet, olivine plus clinopyroxene). Uncommon country rock xenoliths are predominantly tan to beige coloured limestone fragments with lesser basement (gneissic) fragments. The dark matrix is dominated by carbonate, however, it becomes lighter in colour in areas of increased serpentinisation, most commonly near the kimberlite margins. Spherical magmatic globular segregations are locally identifiable, particularly where increased serpentinisation has resulted in a lighter coloured matrix (Figure 1). Thin, late stage calcite veinlets are common, averaging less than $2 \mathrm{~mm}$ but ranging locally up to $10 \mathrm{~mm}$ in thickness. The veinlets increase in concentration towards the contacts and cut country rock xenoliths. Measured orientations indicate they parallel the $\sim 70^{\circ}$ plunge of the kimberlite.

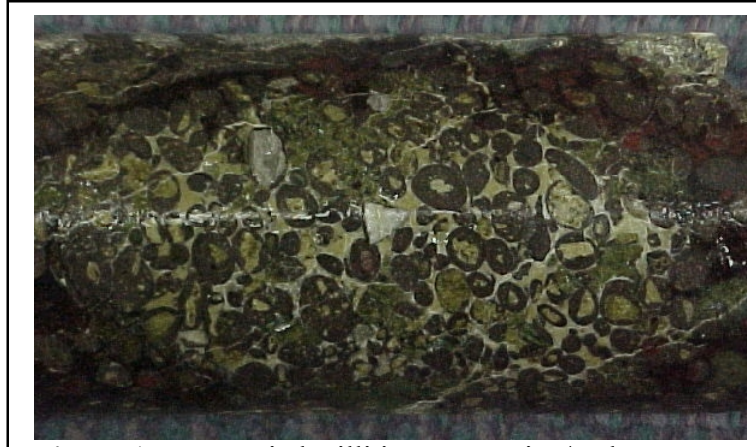

Figure 1: Magmatic lapilli in a serpentine/carbonate matrix interpreted as globular segregations. Small country rock fragment in center of photo does not have a magmatic rind. Diameter of drill core is $63 \mathrm{~mm}$.

In thin section, the kimberlite is classified as a hypabyssal facies, sparsely macrocrystic, calcite kimberlite (terminology after Field and Scott-Smith, 1998). Macrocrysts and abundant olivine phenocrysts are set in a fine-grained calcite dominated matrix. Olivine macrocrysts are subrounded and tend to be partially altered to serpentine and secondary opaque mineral phases. Phlogopite laths (up to $1 \mathrm{~mm}$ ) are present and display pervasive chloritization. Subhedral to anhedral, altered olivine phenocrysts range in size from $0.2 \mathrm{~mm}$ to $0.7 \mathrm{~mm}$ and are evenly distributed through the groundmass. The matrix consists of elongate calcite laths, possible relict melilite (mostly pervasively altered to carbonate) and relatively abundant, small, subhedral opaques set in a base made up predominantly of fine-grained carbonate.

\section{Mineral Chemistry}

Two representative samples of AT-56 have been analyzed in an effort to characterize the mantle sampled by the kimberlite. An initial $600 \mathrm{~g}$ sample (A1020) was crushed and delivered to I\&M Morrison Geological of Delta, BC for visual extraction of indicator minerals. Selected mineral grains from sample A1020 were then sent to RL Barnett Geological of Lambeth, ON for determination of mineral compositions by electron microprobe. A second sample (2701) weighing approximately $4760 \mathrm{~g}$ was submitted to Mineral 
Services Canada for a more representative investigation of the indicator mineral suite of AT-56, with electron microprobe analyses performed at the South African Council for Geoscience and the University of Cape Town. Both samples yielded large heavy mineral concentrates, with the concentrate of sample 2701 representing 26.9 percent of the processed sample weight $(0.3 \mathrm{~mm}$ to $2.36 \mathrm{~mm}$ size fraction). Ilmenite, clinopyroxene, high-Cr garnet and low-Cr garnet are all present in similar concentrations. Chromite is also present, although its abundance is an order of magnitude lower than that of the other minerals

\section{IImenite}

Ilmenite comprises a significant proportion of the heavy mineral concentrates (approximately 25 percent) and is characterized by $\mathrm{MgO}$ contents ranging between 8 and 12 weight percent and elevated $\mathrm{Cr}$ contents of between 2 and 4 weight percent $\mathrm{Cr}_{2} \mathrm{O}_{3}$. A number of ilmenite grains are zoned, with outer rims elevated in $\mathrm{Ti}$ (up to $55 \mathrm{wt} \% \mathrm{TiO}_{2}$ ) and $\mathrm{Mg}$ relative to their cores (Figure 2).

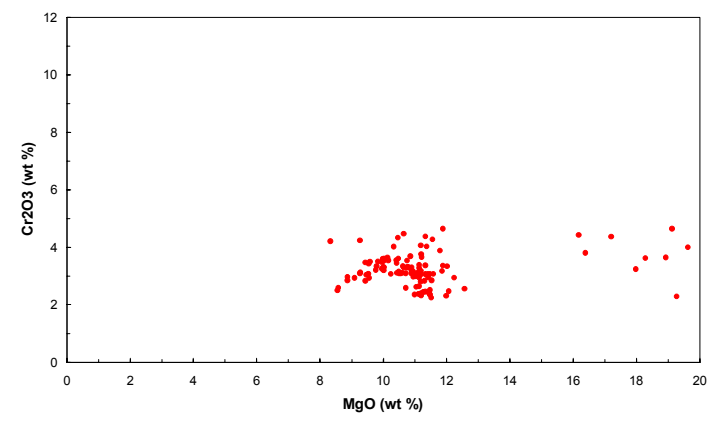

Figure 2: AT-56 ilmenite macrocrysts. Scattered analyses with $16-20 \quad \mathrm{wt} \% \quad \mathrm{MgO}$ represent rim compositions of zoned ilmenites.

\section{Clinopyroxene}

Cr-diopside represents just under 20 percent of the overall mineral abundance of the concentrate, suggesting a strong lherzolitic (and probable wehrlitic) component to the mantle sample represented. Crdiopside grains typically have $\mathrm{CaO}$ contents ranging from 14 to 23 weight percent and $\mathrm{Cr}_{2} \mathrm{O}_{3}$ contents of 0.5 to 4 weight percent. However, a distinct sub-population of the Cr-diopside is characterized by elevated chromium (2.5-4.0 weight percent $\mathrm{Cr}_{2} \mathrm{O}_{3}$ ) and sodium (3.2-5.0 weight percent $\mathrm{Na}_{2} \mathrm{O}$ ) at $\mathrm{CaO}$ contents of 15 to 18 weight percent.

\section{Chromite}

The few chromite macrocrysts analyzed display $\mathrm{Cr}_{2} \mathrm{O}_{3}$ contents of 31 to 57 weight percent, and $\mathrm{TiO}_{2}$ contents of either $<0.7$ weight percent ( 4 grains) or 2 to 6 weight percent (6 grains). The four low $\mathrm{TiO}_{2}$ grains are interpreted as xenocrysts whereas the high $\mathrm{TiO}_{2}$ group is interpreted as representing a likely phenocryst trend, showing increasing $\mathrm{MgO}$ contents with increasing $\mathrm{Cr}_{2} \mathrm{O}_{3}$.

\section{Garnet}

The garnet population of AT-56, comprising approximately half of the heavy mineral concentrates produced, consists of both high- and low-Cr varieties, with the former being only slightly more abundant than the latter. The high-Cr peridotitic garnet population predominantly belongs to the G9 (lherzolitic) trend with only a few (less than 10 percent) weakly sub-calcic G10 (harzburgitic) garnets present (classification of Gurney, 1984). Chrome contents range up to 11 weight percent $\mathrm{Cr}_{2} \mathrm{O}_{3}$ with most grains ranging from 4 to 8 weight percent $\mathrm{Cr}_{2} \mathrm{O}_{3}$ (Figure 3). The lherzolitic trend defined by AT-56 G9 garnets is slightly displaced to higher $\mathrm{Ca}$ values with respect to the ' $85 \%$ line' used to define G9 and G10 garnet populations.

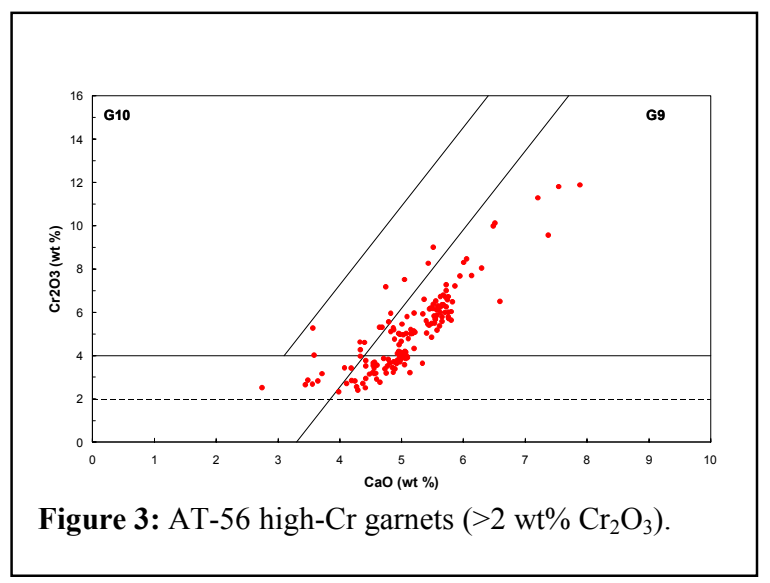

Low Cr-garnets, containing less than 2 weight percent $\mathrm{Cr}_{2} \mathrm{O}_{3}$, are an important component of the indicator mineral population of AT-56. A small group of these grains display elevated $\mathrm{TiO}_{2}$ contents and likely represent megacrysts (Figure 4). However, a significant proportion of the low-Cr garnet population is characterized by low titanium $(0.2$ to $0.4 \mathrm{wt} \% \mathrm{TiO} 2)$ and elevated sodium $\left(0.07\right.$ to $\left.0.13 \mathrm{wt} \% \mathrm{Na}_{2} \mathrm{O}\right)$ contents typical of Group 1, diamond inclusion type eclogite garnets. The latter garnet population is further characterized by $\mathrm{Cr}_{2} \mathrm{O}_{3}$ contents of between 1 and 2 
weight percent and $\mathrm{MgO}$ contents of 19-20 weight percent (Table 1).

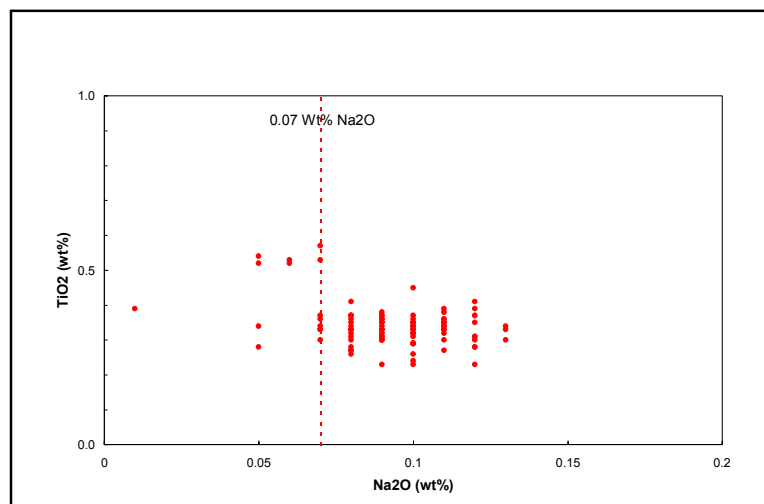

Figure 4: AT-56 low-Cr garnets $\left(<2 \mathrm{wt} \% \mathrm{Cr}_{2} \mathrm{O}_{3}\right)$

\section{Table 1: AT-56 low-Cr garnets - example compositions}

\begin{tabular}{l|c|c|c|c} 
Sample & 2701 & 2701 & $\mathrm{~A} 1020$ & $\mathrm{~A} 1020$ \\
$\mathrm{Grain}$ & 014 & 025 & 15 & 950 \\
\hline $\mathrm{SiO}_{2}$ & 41.46 & 41.46 & 41.90 & 41.48 \\
$\mathrm{TiO}_{2}$ & 0.38 & 0.30 & 0.31 & 0.36 \\
$\mathrm{Al}_{2} \mathrm{O}_{3}$ & 21.74 & 21.33 & 22.85 & 21.47 \\
$\mathrm{Cr}_{2} \mathrm{O}_{3}$ & 0.96 & 1.19 & 1.36 & 1.74 \\
$\mathrm{FeO}$ & 9.67 & 9.43 & 9.69 & 9.74 \\
$\mathrm{MgO}$ & 20.49 & 20.82 & 19.78 & 20.04 \\
$\mathrm{MnO}$ & 0.45 & 0.41 & 0.42 & 0.40 \\
$\mathrm{CaO}$ & 3.76 & 3.66 & 4.19 & 4.45 \\
$\mathrm{Na}$ & 0.11 & 0.13 & 0.08 & 0.09 \\
Total & 99.02 & 98.73 & 100.49 & 99.77
\end{tabular}

\section{NI THERMOMETRY}

A representative population of 24 peridotitic garnets (20 G9 grains and 4 G10 grains) was submitted for trace element analyses using laser ablation, inductively coupled plasma mass spectrometry at the University of Cape Town. Temperatures of equilibrium were calculated for all 24 garnet grains, using the $\mathrm{Ni}$ thermometry calibrations of Ryan et al. (1996). The resultant $\mathrm{Ni}$ temperatures indicate that the majority of the garnets submitted for trace element analyses equilibrated at temperatures ranging from 1000 to 1250 degrees Celsius (Figure 5). Assuming a geotherm of 40 $\mathrm{mW} / \mathrm{m}^{2}$, placing the diamond-graphite boundary at approximately $1000^{\circ} \mathrm{C}$, suggests the majority of the peridotitic garnets from AT-56 are derived from within the diamond stability field. A $40 \mathrm{~mW} / \mathrm{m}^{2}$ geotherm for the Attawapiskat area is consistent with thermobarometry results obtained for 8 garnet- and orthopyroxene-bearing xenoliths from nearby Attawapiskat kimberlites (Scully, 2000).

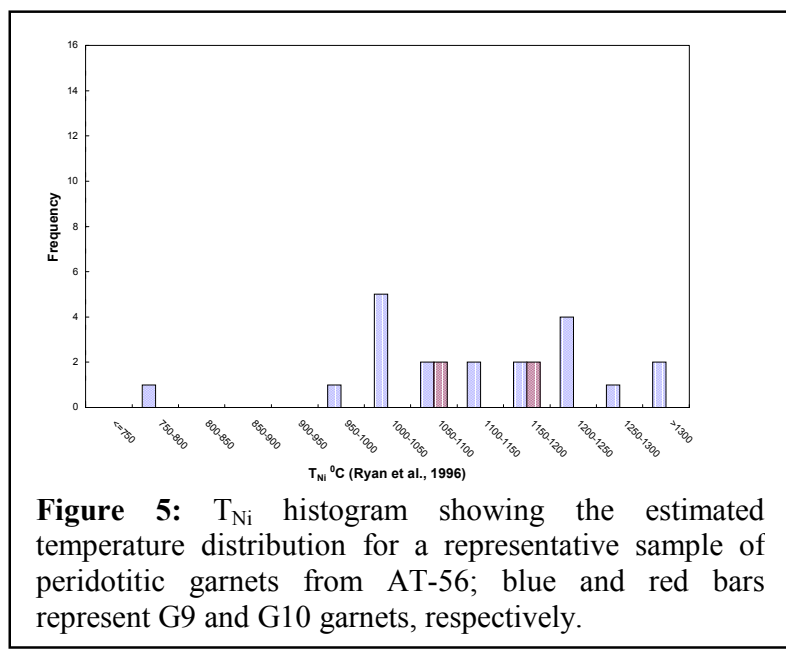

\section{DISCUSSION}

Analysis of heavy mineral concentrates and associated mineral chemistry of AT-56 indicate the kimberlite preserves an extensive sample of the mantle underlying the Superior craton at the time of eruption. Nithermometry results indicate that AT-56 has sampled peridotitic material primarily from within the diamond stability field. The absence of significantly sub-calcic G10 garnets within the AT-56 high-Cr peridotitic garnet population indicates that the peridotitic mantle material that was sampled did not include significant quantities of depleted harzburgite.

AT-56 contains a large population of low-Cr garnet and, although there is no direct method to determine the depth of origin of this population, it may be reasonable to assume it was derived from within the depth range indicated by the peridotitic garnet. The $\mathrm{Ti}$ and $\mathrm{Na}$ contents of this garnet population are similar to garnets found in Group 1, diamond inclusion-type eclogite, however, the $\mathrm{Cr}_{2} \mathrm{O}_{3}$ content of these grains is elevated relative those typically observed in true eclogite. The compositions of these low-Cr garnets are suggestive of derivation from a slightly more mafic source, likely websterite. Na-rich websteritic garnets are known to occur as diamond inclusions and in diamond-bearing websterite xenoliths (Aulbach et al., 2002; Deines et al., 1993; Moore and Gurney, 1989), however these associations are rare and there is a lack of information in the public domain to confirm that Na-rich websteritic garnets can be associated with diamond. 
Comparison of AT-56 garnet compositions with data available for other Attawapiskat area kimberlites suggests populations of Na-rich websteritic garnet may be present elsewhere in the cluster. De Beers' Victor kimberlite, located approximately $3500 \mathrm{~m}$ northwest of AT-56, is presently the subject of a study of the feasibility of constructing a mining operation at the site (www.debeerscanada.com). Similar to AT-56, high-Cr garnets derived from Victor form a lherzolite trend with $\mathrm{Cr}_{2} \mathrm{O}_{3}$ contents ranging from 2 to 9 weight percent (Figure 6). Significantly sub-calcic G10 garnets are also absent in the Victor garnet population. The low-Cr garnet population from Victor is similar to AT-56 low$\mathrm{Cr}$ garnets in that the low-Ti, high-Na grains also display elevated chrome $\left(1-2 \quad w t \% \quad \mathrm{Cr}_{2} \mathrm{O}_{3}\right)$ contents compared to true eclogite (Figure 6).
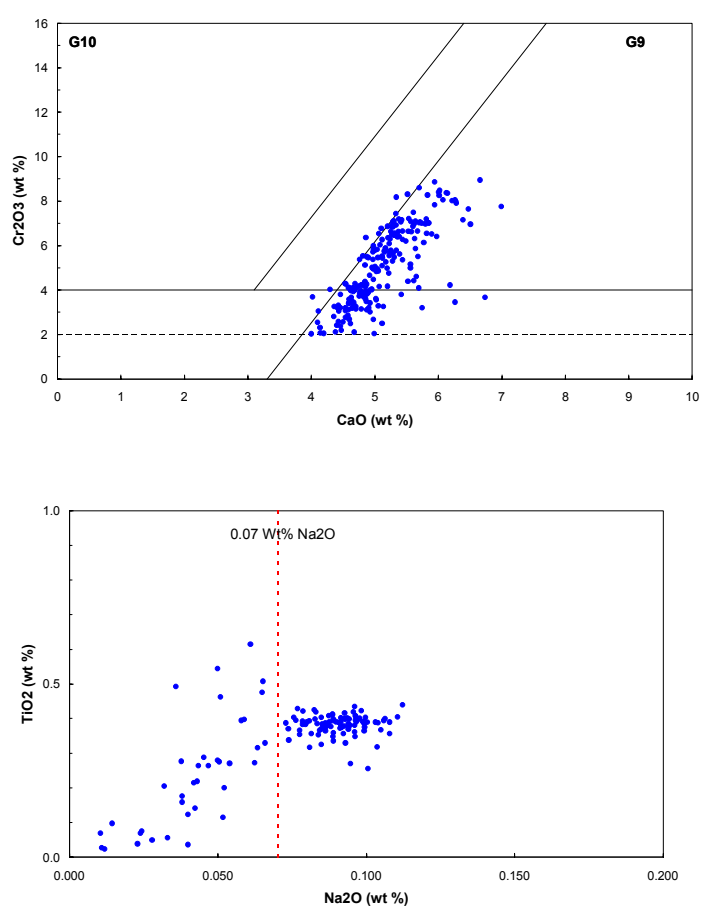

Figure 6: Garnet mineral chemistry for heavy mineral concentrates from the Victor kimberlite. Top: garnets with $>2 \mathrm{wt} \% \mathrm{Cr}_{2} \mathrm{O}_{3}$; Bottom: garnets with $<2 \mathrm{wt} \%$ $\mathrm{Cr}_{2} \mathrm{O}_{3}$; all grains with greater than $0.07 \mathrm{wt} \% \mathrm{Na}_{2} \mathrm{O}$ contain $>1 \mathrm{wt} \% \mathrm{Cr}_{2} \mathrm{O}_{3}$. Data from Sage (2000) and Scully (2000).

A significant population of low-Cr garnet, characterized by high sodium and magnesium contents and 1-2 weight percent $\mathrm{Cr}_{2} \mathrm{O}_{3}$, is present within AT-56 and at least some of the other Attawapiskat cluster kimberlites. This population is interpreted as indicating the presence of a substantial websteritic component to the mantle beneath the north central Superior craton, possibly within the diamond stability field. The lack of strong indicators for the presence of peridotitic diamonds within the Attawapiskat kimberlites may further indicate that this websteritic mantle potentially represents an important diamond reservoir in this area. 


\section{REFERENCES}

Aulbach, S., Stachel, T., Viljoen, K.S., Brey, G.P., and Harris, J.W., 2002. Eclogitic and websteritic diamond sources beneath the Limpopo Belt - is slab-melting the link? Contrib. Min. Pet. 143, 56-70.

Deines, P., Harris, J.W., and Gurney, J.J., 1993. Depth-related carbon isotope and nitrogen concentration variability in the mantle below the Orapa kimberlite, Botswana, Africa. Geochim. Cosmochim. Acta 57, 2781-2796.

Field, M. and Scott-Smith, B.H., 1998. Textural and genetic classification schemes for kimberlites: A new prospective. Extended Abstracts of the $7^{\text {th }}$ International Kimberlite Conference, Cape Town, 1998.

Gurney, J.J., 1984. A correlation between garnets and diamonds in kimberlites. In: J.E. Glover and P.G.Harris (Eds), Kimberlite Occurrence and Origin: A Basis for Conceptual Models In Exploration. U. of W. Australia, Publication No. 8, pp. 143-166.

Heaman, L.M. and Kjarsgaard, B.A., 2000. Timing of eastern North American kimberlite magmatism: continental extension of the Great Meteor hotspot track? Earth Planet Sci. Let. 178, pp. 253-268.

Kong, J.M., Boucher, D.R., and Scott-Smith, B.H., 1999. Exploration and geology of the Attawapiskat kimberlites, James Bay lowlands, northern Ontario, Canada. In: The J.B. Dawson Volume: Proceedings of the VIIth International Kimberlite Conference (Vol. 1); pp. 452-468.

Moore, R.O. and Gurney, J.J., 1989. Mineral inclusions in diamond from the Monastery kimberlite, South Africa. In: Kimberlites and Related Rocks, Volume 2, Their Mantle/crust Setting, Diamonds, and Diamond Exploration. Geological Society of Australia Special Publication No. 14, pp.1029-1041.

Ryan, C.G., Griffin, W.L., and Pearson, N.J., 1996. Garnet geotherms: Pressure-temperature data from Cr-pyrope garnet xenocrysts in volcanic rocks. J. Geophys. Res. 101 (B3), pp. 5611-5625.

Sage, R.P., 2000. Kimberlites of the Attawapiskat area, James Bay Lowlands, northern Ontario. Ontario Geological Survey, Open File Report 6019, 341p.

Scully, K.R., 2000. Mantle xenoliths from the Attawapiskat kimberlite field, James Bay Lowlands, Ontario. M.Sc. Thesis, University of Toronto, Canada

Contact: Ken Armstrong, 1300-409 Granville St., Vancouver, BC, Canada, V6C 1T2, E-mail: nvr_karmstrong@telus.net 